\begin{tabular}{|c|c|c|c|c|}
\hline $\begin{array}{c}\text { 118SHARE: SOCIAL WORK } \\
\text { JURNAL }\end{array}$ & VOLUME: 7 & NOMOR: 1 & HALAMAN: $1-129$ & $\begin{array}{l}\text { ISSN:2339 -0042 (p) } \\
\text { ISSN: 2528-1577 }(e)\end{array}$ \\
\hline
\end{tabular}

\title{
UPAYA PENCEGAHAN HIV/AIDS PADA KALANGAN REMAJA DI KOTA BANDUNG
}

\author{
Oleh: \\ Meilanny Budiarti Santoso ${ }^{1}$, Nurliana Cipta Apsari ${ }^{2}$, Annisa Nabila ${ }^{3}$ \\ 1. Pusat Studi Kesejahteraan Anak dan Keluarga FISIP-Universitas Padjadjaran \\ 2. Pusat Studi Kesejahteraan Anak dan Keluarga FISIP-Universitas Padjadjaran
}

3. Alumni Program Studi Sarjana (S-1) Ilmu Kesejahteraan Sosial FISIP-Universitas Padjadjaran

Email:

(meilannybudiarti13@gmail.com; nurliana.cipta.apsari@unpad.ac.id; nabila annisa_nurhayyu@hotmail.com)

\begin{abstract}
Abstrak
Masalah HIV/AIDS menjadi masalah kontemporer yang berkaitan dengan perilaku berisiko manusia, karena masalah ini bukanlah masalah kesehatan semata. Orang dengan HIV/AIDS (ODHA) termasuk populasi yang rentan bermasalah secara sosial, ekonomi, budaya dan politik. Sejak tahun 2005, sosialisasi tentang bahaya HIV/AIDS yang merupakan salah satu wujud upaya pencegahan HIV/AIDS, sebetulnya sudah mulai masuk ke setiap SMA, namun, karena HIV/AIDS banyak menyerang usia produktif, termasuk pelajar, sehingga sosialisasi diharapkan tidak hanya dilakukan pada para pelajar SMA saja, melainkan juga dilakukan pada para pelajar di tingkat pendidikan yang lebih rendah lagi, yaitu SMP dengan harapan dapat mencegah lebih banyak remaja yang terlibat dalam perilaku seksual yang beresiko dan penyalahgunaan narkoba.

Penelitian ini menggunakan pendekatan penelitian kuantitatif dengan jenis penelitian survei. Metode yang digunakan dalam penelitian ini adalah eksplanatory survey. Populasi dari penelitian ini adalah siswa-siswi SMPN 35 Bandung yang telah mendapat program HEBAT secara penuh 2 semester

Program HEBAT! menjadi pelopor program pencegahan HIV/AIDS yang diperuntukkan bagi remaja di tingkat Sekolah Menengah Pertama (SMP). Program HEBAT! berbentuk kurikulum (mata pelajaran) yang berlangsung selama 2 semester di kelas VIII SMP. Sejak pertengahan tahun 2010, program HEBAT hingga saat ini telah berlangsung di 33 SMP di Kota Bandung. Berdasarkan data yang diperoleh dalam penelitian ini, terdapat pengaruh antara pelaksanaan program HEBAT terhadap sikap remaja. Pendidikan yang diberikan pada remaja dalam program HEBAT adalah sebagai langkah untuk meningkatkan pengetahuan remaja terkait bahaya narkoba dan pentingnya menjaga kesehatan reproduksi sejak dini agar mereka terhindar dari perilaku berisiko HIV/AIDS
\end{abstract}

\section{Kata kunci: HIV/AIDS; Pencegahan}

\begin{abstract}
HIV/AIDS is one of the contemporer issue in connection with precarious behavior of a man, because this is not merely health issue. Person with HIV/AIDS is included into vulnerable population in social, economic, cultural and political. Since 2005, the socialization on the danger of HIV/AIDS as part of prevention effort, have entered high schools, however, due to many productive age impacted by HIV/AIDS, then the socialization is now aiming at population as young as students of junior high schools. It is hoped that this prevention program will be able to prevent many more young people involved in hazardous sexual behavior and drugs abuse.
\end{abstract}


This research is using quantitative with survey approach. The methode used is explanatory survey. The population is students of SMPN 35 Bandung who have received HEBAT programme fully for 2 semesters.

The HEBAT! Program is the pioneer of HIV/AIDS prevention program aiming at young people at junior high school. The HEBAT! Program is formulated in a form of curriculum and blended as subjects at school for 2 semesters in grade 8. Since mid 2010, the HEBAT! Program has run in 33 junior high schools in Bandung City. The research found that there have been influence between the running of HEBAT program toward the attitude of the young people. The education provided to the youth in HEBAT Pogram serves as steps in increasing the knowledge of the young people toward the dangerous of drugs and the importance of keeping the reproduction health since the early age in order for them to avoid the risky behavior of getting HIV/AIDS.

Keywords: HIV/AIDS; prevention.

\section{Pendahuluan}

HIV/AIDS adalah salah satu topik yang tetap menjadi pusat perhatian seluruh dunia, terbukti dengan ditetapkannya penghapusan masalah AIDS dan HIV dalam agenda Suistanaible Development Goals (SDG's) di tahun 2030. Masalah HIV/AIDS menjadi masalah kontemporer yang berkaitan dengan perilaku berisiko manusia, karena masalah ini bukanlah masalah kesehatan semata. Orang dengan HIV/AIDS (ODHA) termasuk populasi yang rentan bermasalah secara sosial, ekonomi, budaya dan politik.

Orang dengan HIV/AIDS tergolong rentan bermasalah secara sosial berkaitan dengan relasi ODHA dengan orang lain di lingkungannya. Masalah sosial yang dialami ODHA terjadi karena orang masih memberikan stigma negatif kepada ODHA sehingga membuat para ODHA enggan untuk berinteraksi dengan masyarakat umum. Selain itu, kekurang pengetahuan masyarakat mengenai penyebaran virus HIV ini membuat orang-orang takut berada di dekat ODHA dan secara sadar maupun tidak sadar telah memperlakukan ODHA secara diskriminatif. Data menunjukkan jumlah orang dengan HIV/AIDS, khususnya di usia remaja semakin meningkat, dan fenomena ini rata terjadi dan tersebar di seluruh dunia (KPA, 2014, Morton, et.al., 1996; Yoo, et.al., 2005, Mahat, et.al., 2011).
Penyebaran dan penularan HIV/AIDS di kalangan remaja sangat berkaitan dengan pengetahuan para remaja mengenai bahaya HIV/AIDS dan proses penyebarannya (Morris, et.al. 2003; Morton, et.al. 1996; Mahat, et.al. 2011; Hyera Yoo, et.al., 2005) juga terkait dengan aspek pengetahuan remaja mengenai kesehatan reproduksi. Menurut data dari Direktorat Jendral Pengendalian Penyakit dan Penyehatan Lingkungan Kementrian Kesehatan Republik Indonesia per tanggal 15 Agustus 2012, menunjukkan untuk rentang usia 15-19 tahun terdapat 1.134 orang yang menderita AIDS. Tentunya, angka tesebut terus bertambah hingga tahun 2017 ini. Usia muda yang diantaranya mempunyai karakteristik ingin bebas, mencari pengalaman, suka mencoba hal-hal baru, emosi cenderung labil sehingga mudah dipengaruhi oleh lingkungan sekitarnya. Selain itu, kerentanan remaja terhadap penyimpangan seksual dan AIDS bersumber pada perubahan fisiologis dan psikologis, yang berkaitan dengan perkembangan organ reproduksi remaja (Singale, 2012).

Sejak tahun 2005, sosialisasi tentang bahaya HIV/AIDS yang merupakan salah satu wujud upaya pencegahan HIV/AIDS, sebetulnya sudah mulai masuk ke setiap SMA (Rita Verita dalam Sopiah, 2009). Namun, karena HIV/AIDS banyak menyerang usia produktif, termasuk pelajar, sehingga sosialisasi diharapkan tidak hanya dilakukan 
pada para pelajar SMA saja, melainkan juga dilakukan pada para pelajar di tingkat pendidikan yang lebih rendah lagi, yaitu SMP dengan harapan dapat mencegah lebih banyak remaja yang terlibat dalam perilaku seksual yang beresiko dan penyalahgunaan narkoba. Oleh karena itu, para remaja membutuhkan pembinaan lebih lanjut sebagai upaya pencegahan penyebaran HIV/AIDS.

Sebagai langkah nyata menanggapi fenomena tersebut, Dinas Pendidikan Kota Bandung dan Komisi Penanggulangan AIDS Kota Bandung beserta tim Laboratorium Penelitian dan Pengabdian Masyarakat (LPPM) Fakultas Kedokteran Universitas Padjadjaran menggagas Program HEBAT! (Hidup Sehat Bersama Sahabat) yang merupakan suatu program pencegahan penularan HIV/AIDS dan juga bertujuan untuk mencegah perilaku berisiko tertular HIV/AIDS di kalangan remaja melalui jarum suntik (narkoba) dan melalui hubungan seksual dini tidak aman.

Program HEBAT! menjadi pelopor program pencegahan HIV/AIDS yang diperuntukkan bagi remaja di tingkat Sekolah Menengah Pertama (SMP). Program HEBAT! berbentuk kurikulum (mata pelajaran) yang berlangsung selama 2 semester di kelas VIII SMP. Sejak pertengahan tahun 2010, program HEBAT hingga saat ini telah berlangsung di 33 SMP di Kota Bandung. Pada semester 1, remaja SMP diberi pendidikan berkenaan dengan pencegahan penyalahgunaan narkoba, termasuk juga tentang bahaya merokok dan alkohol. Adapun pada semester 2, remaja diberi pendidikan berkenaan dengan kesehatan reproduksi remaja terutama berkaitan dengan perubahan fisik, psikis dan sosial di masa pubertas.

\section{Metode}

Penelitian ini menggunakan pendekatan penelitian kuantitatif dengan jenis penelitian survei. Metode yang digunakan dalam penelitian ini adalah eksplanatory survey yaitu metode survei yang digunakan untuk menjelaskan hubungan antara variabelvariabel melalui pengujian hipotesis. Populasi dari penelitian ini adalah siswa-siswi SMPN
35 Bandung yang telah mendapat program HEBAT secara penuh 2 semester. Pada periode tahun 2014-2015, jumlah siswa-siswi yang telah mendapat program HEBAT adalah sebanyak 344 orang.

Teknik pengambilan sampel dilakukan dengan menggunakan Simple Random Sampling, yaitu pengambilan sampel dari populasi yang dilakukan secara acak tanpa memperhatikan strata yang ada dalam populasi. Adapun jumlah sampel dalam penelitian ini adalah $20 \%$ dari 344 orang anggota populasi yaitu 68,8 yang digenapkan menjadi 70 orang.

Instrumen penelitian yang digunakan dalam penelitian ini adalah kuisioner. Proses uji validitas dan reliabilitas dilakukan pada 20 orang di SMPN 12 Bandung. Untuk uji validitas dan uji reliabilitas instrumen penelitian, penulis menggunakan perangkat lunak SPSS (Statistical Product And Solution Services) 15.0. Analisis data dilakukan dengan menggunakan program SPSS (Statistical Product And Solution Services) 15.0. Analisis data yang digunakan adalah analisis regresi linear sederhana.

\section{Pembahasan}

Masa remaja merupakan masa transisi dari masa kanak-kanak menuju masa dewasa, yang melibatkan perubahan biologis, kognitif, maupun emosi. Remaja berada pada tahap kelima dari perkembangan menurut Erikson, yaitu disebut dengan tahap identitas versus kebingungan identitas (identity versus identity confusion). Individu dihadapkan pada tantangan untuk menemukan siapakah mereka, bagaimana masa depannya, arah hidupnya seperti apa yang akan dihadapi serta dihadapkan pada peran baru dan status orang dewasa seperti romantika (Santrock, 2007: 5051). Sejalan dengan Santrock, Hamburg (1979) mengemukakan bahwa dewasa muda usia 1215 tahun, termasuk masa pubertas, merupakan periode kritis dalam perkembangan yang terdiri dari perkembangan pada aspek biologi, psikologi dan tuntutan sosial. Karena perubahan hormonal dan tubuh, terlebih lagi pada perempuan, dan tiba-tiba masuk kepada budaya remaja dengan tekanan dan kebutuhan 
yang baru, hingga periode dewasa muda ini dapat menjadi periode stress dan termasuk dalam usia rawan (Constable dan Flynn, 1982: 10-11).

SMPN 35 Bandung menjadi fokus dalam penelitian ini, karena SMPN 35 Bandung merupakan salah satu sekolah yang secara konsisten melaksanakan program HEBAT hingga saat ini dan SMPN 35 Bandung pun dinobatkan menjadi salah satu sekolah yang dijadikan sampel monitoring evaluasi oleh tim HEBAT pada setiap tahunnya, terhitung sejak diselenggarakannya program HEBAT di SMPN 35 Bandung.

Penelitian ini dilakukan terhadap 70 responden yang merupakan siswa-siswi kelas
IX SMPN 35 Bandung, dengan kata lain telah tuntas selama dua semester menjalani program HEBAT, karena program HEBAT dilaksanakan selama satu tahun dan diperuntukkan bagi remaja kelas VIII SMP. Dalam satu tahun, pelaksanaan program Hebat terbagi menjadi beberapa materi yaitu, pada semester 1 para remaja diberikan materi pendidikan pencegahan penyalahgunaan narkoba, dan pada semester 2 berkenaan kesehatan reproduksi.

Berikut ini topik bahasan dalam pendidikan pencegahan penyalahgunaan narkoba dan pendidikan kesehatan reproduksi yang terdapat dalam program HEBAT diantaranya adalah:

\section{Tabel 4.1.}

\section{Topik Bahasan dalam Program HEBAT}

\begin{tabular}{|l|l|}
\hline $\begin{array}{l}\text { Program Pencegahan Penyalahgunaan } \\
\text { Narkoba }\end{array}$ & $\begin{array}{l}\text { Program Kesehatan } \\
\text { Reproduksi }\end{array}$ \\
\hline $\begin{array}{l}\text { Bahasan terkait: } \\
\text { - Macam Jenis Narkoba }\end{array}$ & $\begin{array}{l}\text { Bahasan terkait: } \\
\text { - Perubahan Fisik, Psikologis, Sosial Terkait Masa } \\
\text { - Efek Narkoba Pada Tubuh } \\
\text { - Tingkatan Pengguna Narkoba }\end{array}$ \\
$\begin{array}{l}\text { - Cara Menghindar dari Penyalahgunaan } \\
\text { Narkoba }\end{array}$ & $\begin{array}{l}\text { Perubahan Fisik } \\
\text { - Proses Kehamilan, Menstruasi, dan Mimpi Basah } \\
\text { - Pertemanan yang Sehat }\end{array}$ \\
- Lingkungan Sekitar Remaja & \\
\hline
\end{tabular}

Sumber: Buku Pegangan Guru HEBAT 2011

Program HEBAT disesuaikan dengan karakteristik remaja usia pubertas ( $\pm 12-15$ tahun), yang dalam penyampaiannya melibatkan keaktifan siswa-siswi. Metode pembelajaran partisipatif yang digunakan dalam program HEBAT diantaranya adalah:

Tabel 2

Metode Pembelajaran Program HEBAT

\begin{tabular}{|l|l|}
\hline Metode & Tujuan \\
\hline Ceramah & Memberikan informasi pada siswa \\
\hline Diskusi kelompok dan debat & $\begin{array}{l}\text { Mendorong siswa untuk: } \\
\text { - Menyampaikan pendapatnya } \\
\text { Tanya jawab antar siswa maupun antara siswa dengan } \\
\text { fasilitator }\end{array}$ \\
\hline Brainstorming (curah pendapat) & Mendorong siswa untuk memunculkan ide baru \\
\hline Lokakarya & $\begin{array}{l}\text { Mendorong siswa untuk mengambil keputusan dan mencoba } \\
\text { materi secara langsung }\end{array}$ \\
\hline $\begin{array}{l}\text { Bermain peran, simulasi, } \\
\text { demonstrasi, studi kasus }\end{array}$ & Mendorong siswa untuk belajar dari pengalaman \\
\hline $\begin{array}{l}\text { Field study (kunjungan), } \\
\text { Observasi, dan pemutaran film }\end{array}$ & Mendorong siswa untuk belajar dari situasi nyata \\
\hline Games (permainan) dan kuis & $\begin{array}{l}\text { Mengembangkan suasana belajar yang nyaman juga } \\
\text { menyenangkan }\end{array}$ \\
\hline
\end{tabular}

Sumber: Buku Pegangan Guru HEBAT 2011 
Karakteristik responden dalam penelitian adalah 52 orang atau $74,3 \%$ berjenis kelamin perempuan dan 18 orang atau $25,7 \%$ berjenis kelamin laki-laki. Sedangkan, terkait dengan usia, responden penelitian terdiri dari dua kategori, yaitu usia 14 tahun sebanyak 57 orang atau $81,4 \%$ dan usia 15 tahun sebanyak 13 orang atau $18,6 \%$.

Program HEBAT yang di dalamnya terdapat berbagai macam materi berkenaan pencegahan penyalahgunaan narkoba, kesehatan reproduksi, dan HIV/AIDS secara umum, disertai dengan penggunaan metode pembelajaran partisipatif yang melibatkan keaktifan seluruh peserta didik dalam penyampaian materi, hingga membuat para siswa-siswi pun menikmati aktifitas-aktifitas dalam pelaksanaan program HEBAT.

Komunikasi yang terjalin dalam penyampaian informasi program HEBAT tidak hanya satu arah seperti ceramah yang sering ditemukan dalam keseharian di sekolah, melainkan komunikasi dua arahlah yang terjalin antara siswa-siswi dengan fasilitator (Guru BK) maupun antar siswa-siswi di kelas, karena peran fasilitator itu bukan hanya sebagai penyampai pesan (materi) akan tetapi juga sebagai pihak yang memfasilitasi agar seluruh siswa-siswi dapat berpartisipasi dalam semua kegiatan di kelas.

Program HEBAT dirancang menyesuaikan dengan kehidupan keseharian remaja yang identik dengan ceria, enerjik, maka dari itu selain peran fasilitator yang diupayakan dapat membawa suasana belajar yang kondusif, nyaman, asyik, untuk menunjang aktifitas dalam kelas, seluruh siswa-siswi pun diberi LKS (Lembar Kerja Siswa) unik secara cuma-cuma (gratis). LKS yang diberikan pada program HEBAT! ini dirancang agar menarik bagi para siswa-siswi, yaitu dengan warna-warna di tiap lembar LKSnya dan juga terdapat gambar-gambar tokoh siswa maupun siswi, guru dan lain-lain, yang menggambarkan kehidupan seorang remaja SMP.

Berdasarkan data yang diperoleh dalam penelitian ini, terdapat pengaruh antara pelaksanaan program HEBAT terhadap sikap remaja. Berdasarkan hasil pengolahan data, variabel pelaksanaan program HEBAT mempengaruhi sikap remaja dalam upaya pencegahan HIV/AIDS sebesar 32,4\%. Dengan demikian, sisanya sebesar $67,6 \%$ dipengaruhi oleh faktor-faktor lain. Faktor lain tersebut diantaranya adalah adanya nilai-nilai agama yang kuat, kebiasaan atau budaya tempat tinggal dan lingkungan sekolah yang mengakibatkan tingginya kontrol sosial yang berlaku di lingkungan remaja, ditambah dengan pesatnya perkembangan ilmu teknologi informasi (media massa) hingga siswa-siswi dapat dengan mudah mengakses informasi, salah satunya adalah melalui smartphone dengan layanan internet di dalamnya yang dimiliki oleh masing-masing siswa-siswi. Hal tersebut menunjukkan bahwa sikap seseorang dapat dibentuk beberapa diantaranya adalah melalui kebudayaan, media massa, lembaga pendidikan dan lembaga agama.

Adanya pengaruh pelaksanaan program HEBAT yang merupakan pendidikan pencegahan HIV/AIDS terhadap sikap remaja, seiring dengan pendapat yang dikemukakan oleh Suyono (2008: 34-35), bahwa sikap dapat berubah dengan cara diantaranya melalui pesan informasi yang dapat menghasilkan perubahan dalam komponen kognitif pada sikap individu. Karakteristik remaja yang labil hingga mudah terpengaruh oleh lingkungan, maka diperlukan penanaman berbagai informasi positif untuk menunjang perkembangan kognitif remaja. Hal tersebut diharapkan agar remaja memiliki bekal pengetahuan (kognitif) positif yang nantinya berlanjut pada aspek sikap lain yaitu perasaan (afektif) positif yang timbul dalam diri remaja, hingga berpengaruh pula pada kecenderungan remaja dalam berperilaku (konatif) positif. Karena pada dasarnya, pembentukan sikap melalui pemberian informasi-informasi, pengetahuan seperti yang dilakukan dalam pelaksanaan program HEBAT, berkaitan dengan aspek kognitif.

Proses pengolahan informasi seperti ini kemudian menimbulkan adanya sebuah kepercayaan terhadap informasi yang didapat. Setelah muncul kepercayaan terhadap suatu informasi, perlahan kepercayaan tersebut pun 
mendorong seorang individu untuk meluapkan reaksi emosi (aspek afektif) tertentu terhadap objek atau informasi yang di dapat. Lalu kemudian reaksi emosi tersebut berproses mengarah pada sebuah kecenderungan untuk melakukan sesuatu yang berkaitan dengan objek atau informasi yang didapat tersebut (aspek konatif).

Pendidikan yang diberikan pada remaja dalam program HEBAT adalah sebagai langkah untuk meningkatkan pengetahuan remaja terkait bahaya narkoba dan pentingnya menjaga kesehatan reproduksi sejak dini agar mereka terhindar dari perilaku berisiko HIV/AIDS. Pengetahuan-pengetahuan yang diberikan tersebut diharapkan dapat menjadi bekal bagi remaja hingga mereka dapat mengaplikasikannya dalam kehidupan keseharian mereka, dan lebih jauh lagi diharapkan dapat membentuk sikap serta perilaku positif pada remaja.

\section{Daftar Pustaka}

Achlis. 1993. Studi Perilaku dan Lingkungan Sosial Manusia (HBSE). Bandung: Koperasi Mahasiswa STKS Bandung.

Arikunto, Suharsimi. 1998. Prosedur Penelitian: Suatu Pendekatan Praktek. Jakarta: Rineka Cipta.

Babbie, Allen Rubin E. 1993. Research Methods For Social Work. California: Cale Publishing Company.

Bungin, M. Burhan. 2005. Metodologi Penelitian Kuantitatif. Jakarta: Prenada Media Group.

Constable, Robert T., Flynn, John P. 1982. School Social Work-Practice and Research Perspectives. Illinois: The Dorsey Press.

Cozby, Paul C. 2004. Methods in Behavioral Research. Mc Graw Hill.

Creswell, John W. 2010. Research DesignPendekatan Kualitatif, Kuantitatif, dan Mixed. Terjemahan Achmad Fawaid. Yogyakarta: Pustaka Pelajar.
Effendi, Sofian dan Tukiran. 2012. Metode Penelitian Survei. Jakarta: LP3ES.

Hamburg, Morris. Basic Statistics: A Modern Approach. Second edition. New York: Harcourt Brace Joanovbich, Inc., 1979

Hinduan, Zahrotur Rusyda., dkk. 2011. HEBAT-Buku Pegangan Guru, Pendidikan Pencegahan Penyalahgunaan Narkoba Program Hidup Sehat Bersama Sahabat (HEBAT!). Bandung.

http://www.jabarprov.go.id/indeks.php/news/ 3536/Minimnya_Pengetahuan_Penyeb ab_Tingginya_Kasus_HIV_AIDS (Diunduh pada hari Jumat, 13 Juni 2014 pukul 10.54 WIB).

Komisi Penanggulangan AIDS Nasional. 2013. Laporan Situasi Perkembangan HIV dan AIDS di Indonesia Tahun 2013. http://www.aidsindonesia.or.id (Diunduh pada hari Kamis, 23 Januari 2014 pukul 09.44 WIB)

Mahat, G., Scoloveno, M.A., Ayres, C. 2011. HIV/AIDS Knowledge and SelfEfficacy Among Nepalese Adolescents: A Peer Education Program. Research and Theory for Nursing Practice: An International Journal, Vol. 25, No. 4, 2011, pp. 271-283.

Morton, M., Nelson, L., Walsh, C., Zimmerman, S., \& Coe, R. 1996. Evaluation of HIV/AIDS Education Programs for Adolescents. Journal of Community Health, Vo. 21 No. 1 February, 1996, pp. 23-35.

Monks, F.J., Knoers, AMP., Haditono, Siti Rahayu. 2006. Psikologi Perkembangan. Yogyakarta: Gadjah Mada University Press.

Raharjo, ST. 2015. "Pekerjaan Sosial Generalis, Suatu Pengantar Bekerja Bersama Organisasi dan Komunitas", Edisi Revisi Buku, Unpad Press,

Raharjo, ST. 2015. "Dasar Pengetahuan Pekerjaan Sosial", Buku, Unpad Press 


\begin{tabular}{|c|c|c|c|c|}
\hline $\begin{array}{c}\text { 118SHARE: SOCIAL WORK } \\
\text { JURNAL }\end{array}$ & VOLUME: 7 & NOMOR: 1 & HALAMAN: 1 - 129 & $\begin{array}{l}\text { ISSN:2339 -0042 }(p) \\
\text { ISSN: 2528-1577 }(e)\end{array}$ \\
\hline
\end{tabular}

Raharjo, ST., Taftazani, BM., Apsari, NC., Santoso, MB. 2016. "PANDUAN PRAKTIKUM MIKRO (Konseling dan Pengembangan Diri)". Buku . Unpad Press.

Raharjo, ST. 2015. "Assessment dan Wawancara dalam Prakti Pekerjaan Sosial dan Kesejahteraan Sosial", Edisi Revisi Buku, Unpad Press

Santrock, John W. 2007. Remaja. Jakarta: Erlangga.

Singale, Lastianti. 2012. Hubungan Antara Pengetahuan dan Sikap tentang HIVI AIDS dengan Tindakan Pencegahan HIV/AIDS pada Siswa SMKN 3 Tahuna. Skripsi Kesehatan Masyarakat. Manado: Fakultas Kesehatan Masyarakat Universitas Sam Ratulangi.

Sopiah, Pipih. 2009. Lindungi Pelajar Dari Serangan Virus HIV/AIDS. Bandung: PT Elisa Surya Dwitama.

Suyono, Hadi. 2008. Pengantar Psikologi Sosial 1. Yogyakarta: D\&H Pro Media.

Yoo, H., Lee, S.H., Kwon, B.E., Cung, S., \& Kim, S. 2005. HIV/AIDS Knowledge, Attitude, Related Behaviors and Sources of Information Among Korean Adolescents. The Journal of School Health, Vol 75 No. 10 December 2005, pp. $393-399$. 